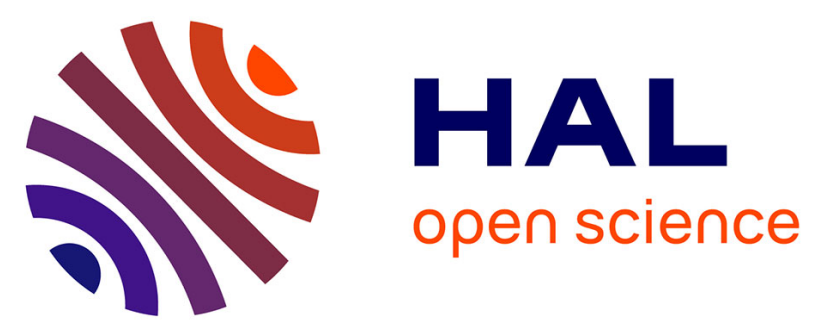

\title{
Reactive Organosolv Lignin Extraction from Wheat Straw: Influence of Lewis Acid Catalysts on Structural and Chemical Properties of Lignins
}

Sandra Constant, Charlie Basset, Claire Dumas, Francesco Di Renzo, Mike Robitzer, Abdellatif Barakat, Françoise Quignard

\section{To cite this version:}

Sandra Constant, Charlie Basset, Claire Dumas, Francesco Di Renzo, Mike Robitzer, et al.. Reactive Organosolv Lignin Extraction from Wheat Straw: Influence of Lewis Acid Catalysts on Structural and Chemical Properties of Lignins. Industrial Crops and Products, 2015, 65, pp.180-189. 10.1016/j.indcrop.2014.12.009 . hal-01093037

\section{HAL Id: hal-01093037 https://hal.science/hal-01093037}

Submitted on 8 May 2018

HAL is a multi-disciplinary open access archive for the deposit and dissemination of scientific research documents, whether they are published or not. The documents may come from teaching and research institutions in France or abroad, or from public or private research centers.
L'archive ouverte pluridisciplinaire $\mathbf{H A L}$, est destinée au dépôt et à la diffusion de documents scientifiques de niveau recherche, publiés ou non, émanant des établissements d'enseignement et de recherche français ou étrangers, des laboratoires publics ou privés. 


\title{
Reactive organosolv lignin extraction from wheat straw: Influence of Lewis acid catalysts on structural and chemical properties of lignins
}

\author{
Sandra Constant ${ }^{\mathrm{a}}$, Charlie Basset ${ }^{\mathrm{a}}$, Claire Dumas ${ }^{\mathrm{b}}$, Francesco Di Renzo ${ }^{\mathrm{a}}$, Mike Robitzer ${ }^{\mathrm{a}}$, \\ Abdellatif Barakat ${ }^{\mathrm{c}, *}$, Françoise Quignard ${ }^{\mathrm{a}, * *}$ \\ a ICGM, UMR 5253 CNRS-UM2-ENSCM-UM1, Matériaux Avancés pour la Catalyse et la Santé, 8 Rue de l'Ecole Normale, 34296 Montpellier, France \\ ${ }^{\mathrm{b}}$ LISBP-INSA de Toulouse, INSA/CNRS 5504-UMR INSA/INRA 792, 135 avenue de Rangueil, 31077 Toulouse CEDEX 04, France \\ ' INRA, IATE 1208 Ingénierie des Agropolymères et Technologies Emergentes 2, Place Pierre Viala 34060 Montpellier CEDEX 1, France
}

\begin{abstract}
Lewis acids have been studied as catalysts in the organosolv treatment of wheat straw. Fractionation of the lignocellulosic biomass and fragmentation of lignin have been performed in aqueous ethanol in the presence of $\mathrm{FeCl}_{2}, \mathrm{CuCl}_{2}, \mathrm{FeCl}_{3}, \mathrm{Ga}(\mathrm{OTf})_{3}, \mathrm{ZrOCl}_{2}$ or $\mathrm{Sc}(\mathrm{OTf})_{3}$. The lignins were characterised in terms of molecular weight, $\beta \quad 0 \quad 4$ linkage content and chemical functions through size exclusion chromatography; thioacidolysis; ${ }^{31} \mathrm{P}$ and ${ }^{13} \mathrm{C}$ NMR spectroscopies. The degree of delignification and the yield of Klason lignin increased with the hardness of the Lewis acid. About half of the delignification products were water-soluble monomers and oligomers. The nature of the Lewis acid influenced also the characteristics of the precipitated lignins. The molecular mass, the amount of $\mathrm{OH}$ groups and of aliphatic $\mathrm{C} O \mathrm{O}$ bonds decreased as cation hardness increased.
\end{abstract}

\section{Introduction}

Lignin is a polyphenolic amorphous material derived primarily from the dehydrogenative radical polymerization of monolignols ( $p$-coumaryl-, coniferyl- and sinapyl-alcohols). Each of these monolignols results in a different type of lignin units: $p$-hydroxyphenyl $(H)$, guaiacyl $(G)$, and syringyl $(S)$ units, respectively, which vary according to growing place, maturity and localization in the cell. Lignin generally shows an irregular structure with a highly condensed cross-linked polymer network. Lignin composition varies in different groups of vascular plants, being G-, GS-, and HGStype lignin characteristic for softwoods (woody gymnosperms), hardwoods (woody angiosperms), and grasses plants, respectively. These native lignins include both condensed inter-unit linkages (5$C-5^{\prime}, 4-0-5^{\prime}$, and $\left.5-5^{\prime}\right)$ and aryl ether linkages $(\beta-0-4, \beta-\beta$ and $\beta-5)$, the $\beta-0-4$ bonds being the most frequent in natural lignins (Fig. 1) (Gösta and Knut, 2010).

The characteristics of extracted lignins (technical lignins) are dependant both on biomass resource and extraction process. Lignin obtained as a by-product of the kraft pulping has high

\footnotetext{
* Corresponding author. Tel.: +33 4 99612581; fax: +33 499613076.

** Corresponding author. Tel.: +33 46716 3460; fax: +33 467163470

E-mail addresses: barakat@supagro.inra.fr (A. Barakat), quignard@enscm.fr (F. Quignard).
}

sulphur content and is primarily burned for thermal energy production and sulphur recycling. Organosolv process was developed in the 70-80s as an efficient and sulphur-free way to produce high-quality pulp from northern hardwoods (Berlin et al., 2013; Pye and Lora, 1991). In this process, biomass is treated with an aqueous solution of organic solvent (e.g. ethanol) at high temperature with or without a catalyst (sulphuric or other acids). This pre-treatment achieves an efficient fractionation of the cellulose-hemicellulose-lignin matrix in three separate streams containing cellulose, hemicellulose-derived products and ligninderived products. The recovered insoluble cellulosic substrate is more susceptible to enzymatic hydrolysis and the solubilised organosolv lignins are recognised as high-quality technical lignins (Stephen et al., 2012). Lewis acids have been proposed to improve fractionation of lignocellulose by acidolysis (Lachenal et al., 2004) and organosolv pulping (Yawalata and Paszner, 2004). Recently, while studying the pre-treatment for enzymatic degradation of cellulose, Kim et al., 2010 have shown that using Lewis acids during organosolv process allows an effective dissolution of hemicelluloses contained in the straw, liberating lignin-although the authors did not specifically isolate and characterise it. Recently Huijgen et al. studied, among others, a $\mathrm{MgCl}_{2}$-catalyzed organosolv fractionation process which seemed to more selectively improve delignification of willow wood (Huijgen et al., 2011). 
<smiles>C=Cc1cc(OC)c(OC)c(OC)c1</smiles>

$S$

Syringyl<smiles>COc1cc(I)cc(OC)c1OC(CO)C(O)C(O)c1ccccc1</smiles>

$\beta-\mathrm{O}-4$ $(\beta$-aryl ether $)$<smiles>CCOc1cc(OC)cc(Cc2cc(OC)cc(OC)c2C)c1C</smiles>

$5-\mathrm{C}-5^{\prime}$ (diphenylmethane)<smiles>CCOc1cc(C)ccc1OC</smiles>

G

Guaiacyl<smiles>[Y]C1OC(C2=CC=CC2C)C2COC(c3ccccc3)C12</smiles>

$\beta-\beta$

(resinol)<smiles>COc1cc(C)ccc1Oc1cc([Tl])cc(OC)c1OC</smiles>

$4-0-5^{\prime}$

(diphenyl ether)<smiles>CCOc1ccc(C)cc1</smiles>

$\mathrm{H}$

p-hydroxyphenyl

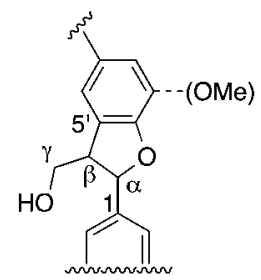

$\beta-5$

(phenylcoumaran)

Fig. 1. Main inter-units linkages and building blocks found in lignin.

Disruption of linkages in lignin represents a potential route for the production of a wide range of phenolic compounds for adhesives, resins, flavours, biochemicals and biofuels (Stewart, 2008; Sun, 2010; Thakur et al., 2014; Wang et al., 2009). The catalyst and the process for catalytic fragmentation of lignins have to be chosen according to the structural and chemical properties of the lignin to be fragmented (Zakzeski et al., 2012; Zakzeski and Weckhuysen, 2011).

In this context, the present paper evaluates the interest of Lewis acid catalysed organosolv fractionation of wheat straw. Transition metal salts are known to be effective catalysts of oxidative degradation of lignin (Zakzeski et al., 2010). The present process is expected to couple fractionation and fragmentation. The impact of several transition metal salts on the structural and chemical characteristics of the technical lignins obtained is addressed.

\section{Materials and methods}

\subsection{Materials}

The straw used in this study was collected from a single harvesting of soft wheat (Triticum aestivum) from a local organic farm. The straw stock, which was collected in summer 2010, consists of $90 \mathrm{~kg}$ in 6 bales. Straw drying was performed at room temperature on field. The straw was subjected to a succession of knife mill grindings, first with a $5 \mathrm{~cm}$ grid, then with a $1 \mathrm{~cm}$ grid. The composition of the straw was cellulose $44.3 \%$, hemicelluloses $24.5 \%$ (xylose $19.1 \%$, arabinose $3.3 \%$, galacturonic acid $1.1 \%$ ), lignin $22.34 \%$, proteins $3.1 \%$, and ashes $3.4 \%$. The metal salts and reagents were purchased from Sigma-Aldrich. Gallium triflate was purchased from Strem.

\subsection{Pulping}

The process is a classical organosolv process. In a typical experiment, $40 \mathrm{~g}$ of wheat straw was mixed in $1.25 \mathrm{~L}$ of aqueous ethanol (EtOH $65 \%, \mathrm{H}_{2} \mathrm{O} 35 \%$ ) with $8 \mathrm{mmol} \mathrm{L}^{-1}$ catalyst in a $2 \mathrm{~L}$ autoclave (Autoclave France ${ }^{\circledR}$ ). A benchmark experiment was carried out by using $4.4 \mathrm{mmol} \mathrm{L}^{-1} \mathrm{H}_{2} \mathrm{SO}_{4}$ in the same conditions. The mixture was stirred during $2 \mathrm{~h}$ at $160^{\circ} \mathrm{C}$. Upon completion of the reaction, the reactor was cooled down to room temperature. Pulp and black liquor were separated from the reaction mixture using a nylon filter. The pulp was washed three times with $300 \mathrm{~mL}$ of an aqueous ethanol solution at $60^{\circ} \mathrm{C}$ and the washes combined with the black liquor. Three volumes of water were added to the resulting liquor in order to precipitate the lignin. The solution obtained was centrifuged at $20^{\circ} \mathrm{C}$ with $4950 \mathrm{rpm}$ for $20 \mathrm{~min}$ and filtered under vacuum using Whatman ${ }^{\circledR}$ No 1 filters. The precipitate was washed with water and dried at $50^{\circ} \mathrm{C}$ for $72 \mathrm{~h}$. In this paper, the precipitate is defined as lignin fraction and the filtrate as aqueous ethanol fraction in which extractible compounds were dissolved.

\subsection{Lignin characterization}

The different lignins are characterised by the common procedure described in literature (Tamminen, 1999).

\subsubsection{Klason method}

The carbohydrate and lignin compositions of the extracted lignins were measured using a Klason method (Sluiter et al., 2008) in conditions optimised for the analysis of sugars (Renard et al., 1998). The dried samples $(100 \mathrm{mg})$ were treated with $1.25 \mathrm{~mL}$ of 
Table 1

Influence of Lewis acids on the degree of delignification and the yields of phenolic products (w/w).

\begin{tabular}{|c|c|c|c|c|c|}
\hline Catalyst & $\begin{array}{l}\text { Cation } \\
\text { hardness } \\
(\mathrm{eV})\end{array}$ & $\begin{array}{l}\text { Straw delignification } \\
(\%)\end{array}$ & $\begin{array}{l}\text { Precipitated lignin } \\
(\%)\end{array}$ & $\begin{array}{l}\text { Phenolic monomers } \\
(\%)\end{array}$ & $\begin{array}{l}\text { Soluble phenolic derivatives }{ }^{b} \\
(\%)\end{array}$ \\
\hline $\mathrm{H}_{2} \mathrm{SO}_{4}$ & 1 & 90 & 47.1 & 1.5 & 41.8 \\
\hline $\mathrm{FeCl}_{2}$ & 7.2 & 61 & 31.4 & 1.2 & 28.1 \\
\hline $\mathrm{CuCl}_{2}$ & 8.3 & 64 & 33.1 & 0.5 & 30.2 \\
\hline $\mathrm{FeCl}_{3}$ & 13.1 & 85 & 43.8 & 1 & 40.3 \\
\hline $\mathrm{Ga}(\mathrm{OTf})_{3}{ }^{\mathrm{c}}$ & 16.6 & 85 & 66 & 1.3 & 17.9 \\
\hline $\mathrm{ZrOCl}_{2}$ & 23 & 86 & 42.6 & 1.4 & 42.2 \\
\hline $\mathrm{Sc}(\mathrm{OTf})_{3}$ & 24.4 & 85 & 44.6 & 0.8 & 39.7 \\
\hline
\end{tabular}

a Phenolic derived Expressed as Klason lignin.

b Missing lignin including oligomers and lignin carbohydrate complexes.

c The catalytic extraction with $\mathrm{Ga}(\mathrm{OTf})_{3}$ was performed in triplicate to confirm this high value.

$72 \% \mathrm{H}_{2} \mathrm{SO}_{4}$ at ambient temperature for $1 \mathrm{~h}$. The solutions were diluted with water to $12 \% \mathrm{H}_{2} \mathrm{SO}_{4}$ and heated at $100^{\circ} \mathrm{C}$ for $2 \mathrm{~h}$. The hydrolysates were filtered under vacuum with Whatman ${ }^{\circledR}$ GFF F filters. The Klason lignin content (Lks) was determined as the gravimetric residue after $\mathrm{H}_{2} \mathrm{SO}_{4}$ hydrolysis. For this purpose, assumption has been made that the Klason lignin of the starting material is not overestimated with non-lignin acid insoluble products. The determinations reported here have been duplicated.

In order to correctly evaluate the effectiveness of Lewis acids in organosolv pulping, yields, degree of delignification and selectivities are expressed in Klason lignin with an ash content correction (Table 1). Knowing the quantity of Lks initially present in the native wheat straw and the quantity of Lks in the lignocellulosic residue allowed determining the degree of straw delignification as shown in Eq. (1):

Degree of delignification $=\frac{m_{\mathrm{Lks}} \text { straw }-m_{\mathrm{Lks}} \quad \text { residue }}{m_{\mathrm{Lks}} \text { straw }}$

with $m_{\text {Lks straw }}=m_{\text {straw }} \times \%_{\text {Lks }}$ straw and $m_{\text {Lks residue }}=m_{\text {residue }} \times$ \%Lks residue.

The yield of Lks was calculated from the amount of Lks in the precipitate relative to the initial quantity of Klason lignin in the straw (Eq. (2)):

Yield of Lks $=\frac{m_{\text {Lks precipitate }}}{m_{\text {Lks }} \text { straw }} \times 100$

with $m_{\text {Lks }}$ precipitate $=m_{\text {precipitate }} \times \%_{\text {Lks }} \quad$ precipitate

The selectivity was defined as the yield of lignin reported to the degree of delignification. The monomer selectivity in the delignification products was calculated by analysis with GC-MS and the selectivity in oligomer and LCC was determined from the balance of the delignification products.

The filtrates were analyzed for sugars on high-pressure liquid chromatography (HPLC). HPLC analysis was used to quantify monosaccharides (glucose, xylose, arabinose). The analysis was done with a combined HPLC water system, using a BioRad HPX$87 \mathrm{H}$ column at $50^{\circ} \mathrm{C}$. The solvent was $0.005 \mathrm{M} \mathrm{H}_{2} \mathrm{SO}_{4}$ and flow rate $0.3 \mathrm{~mL} / \mathrm{min}$. The recovery of monosaccharides was determined by standard addition (D-fucose) to the samples. A refractive index (RI) detector (waters) was used to quantify carbohydrates. The system was calibrated with glucose, xylose, arabinose standards (Sigma-Aldrich). Before measurements, all the samples $(1 \mathrm{~mL})$ were filtered through $0.22 \mu \mathrm{m}$ nylon filters.

The compositions of lignins in Klason insoluble lignin, sugars and residual metals and ashes are reported in Table S1. Metal content were measured by inductively coupled plasma optical spectroscopy after mineralization in acid medium at CNRS Central Analysis Service in Solaize (France).

\subsubsection{Mass spectrometry analysis}

Thioacidolysis: the extracted lignin polymers were degraded using thioacidolysis to estimate the content of $\beta-0-4$ linked structures according to Lapierre's procedure (Lapierre et al., 1986). Before each injection, the samples were derivatised with $\mathrm{N}, \mathrm{O}-$ bis(trimethylsilyl) trifluoroacetamide. Tetracosane was used as internal standard. All the determinations reported here have been performed twice.

To elucidate the monomer structures, the aqueous ethanol fractions were extracted with ethyl acetate with a separatory funnel, concentrated under reduced pressure and then analysed by GC-MS.

The GC-MS apparatus used was a Shimadzu GC-MS - QP 2010 Plus equipped with a $\mathrm{SLB}^{\mathrm{TM}}-5 \mathrm{~ms}$ column and a Quadrupole mass detector.

\subsubsection{Size exclusion chromatography}

2.3.3.1. Acetylation of lignins. Approximately $200 \mathrm{mg}$ of lignins were acetylated with acetic anhydride/pyridine $(1 / 1, v / v)$ at room temperature for $24 \mathrm{~h}$ in $100 \mathrm{~mL}$ round-bottom flask, under nitrogen, as described previously (Heitner et al., 2001). The concentration of the lignin in this solution was approximately $50 \mathrm{mg} \mathrm{mL}^{-1}$. After $24 \mathrm{~h}$, the solution was diluted with $\sim 30 \mathrm{~mL}$ of ethanol and stirred for an additional $30 \mathrm{~min}$, after which the solvents were removed with a rotary evaporator. Repeated addition and removal of ethanol allowed for the removal of acetic acid and pyridine from the sample. The residue was then dissolved in chloroform, washed twice with filtered de-ionised water in a separatory funnel, and dried with anhydrous sodium sulphate. The chloroform solution $(\sim 10 \mathrm{~mL})$ was added dropwise to approximately $150 \mathrm{~mL}$ of anhydrous ether and the product collected as a precipitate. The precipitate was washed twice with ether, each time being collected by centrifugation $(20 \mathrm{~min}, 3000 \mathrm{rpm})$. The precipitate was dried under high vacuum at $40^{\circ} \mathrm{C}$ for $24 \mathrm{~h}$.

2.3.3.2. Molecular weight distributions. Molecular weight distributions of lignins and acetylated lignins were analyzed by gel permeation chromatography (GPC) using Varian apparatus equipped with an RI Shodex refractive index detector. Two PL-gel Mixed-D columns were used at $70^{\circ} \mathrm{C}$ with a $0.8 \mathrm{~mL} \mathrm{~min}^{-1}$ flow rate of DMF, calibrated with poly(methyl methacrylate) standards.

Molecular weight distributions of phenolic derived oligomers were analyzed by GPC using a Varian Q50 GPC with a differential refractive index detector and a column PL-gel Mixed-C. Tetrahydrofuran was used as eluent at $1.0 \mathrm{~mL} \mathrm{~min}^{-1}$. Calibration of the GPC equipment was carried out using polystyrene standards.

\subsubsection{NMR analysis}

2.3.4.1. Lignin and reagents. Prior to derivatization, all lignins were dried for $48 \mathrm{~h}$ under vacuum at $40^{\circ} \mathrm{C}$ in the presence of silica gel (Sigma, type III). All solvents and chemicals from Sigma were of reagent grade. Pyridine was stored over molecular 
sieve (type $4 \AA$ ) under nitrogen. 2-Chloro-4,4,5,5-tetramethyl1,3,2-dioxaphospholane and chromium(III) acetylacetonate were stored at $3{ }^{\circ} \mathrm{C}$.

2.3.4.2. Phosphorylation. A solvent mixture composed of pyridine and $\mathrm{CDCl}_{3}$ in a $1.6 / 1 \mathrm{v} / \mathrm{v}$ ratio was prepared, on the basis of considerations outlined previously (Granata and Argyropoulos, 1995). The solution was protected from moisture with molecular sieves (type $4 \AA$ ) and kept in a sealed container under nitrogen.

Internal standard solution: cyclohexanol $\left(10 \mathrm{~g} \mathrm{~L}^{-1}\right)$ in pyridine $/ \mathrm{CDCl}_{3} 1.6 / 1 \mathrm{v} / \mathrm{v}$ ratio.

Relaxation reagent solution: chromium(III) acetylacetonate $\left(5 \mathrm{~g} \mathrm{~L}^{-1}\right)$ in pyridine $/ \mathrm{CDCl}_{3} 1.6 / 1 \mathrm{v} / \mathrm{v}$ ratio.

$30 \mathrm{mg}$ of lignin were accurately weighed into a $1 \mathrm{~mL}$ volumetric flask. The sample was then dissolved in $0.5 \mathrm{~mL}$ of the above solvent mixture. 2-Chloro-4,4,5,5-tetramethyl-1,3,2dioxaphospholane $(100 \mu \mathrm{L})$, internal standard solution $(100 \mu \mathrm{L})$ and relaxation reagent solution $(100 \mu \mathrm{L})$ were added. Finally, the solution was made up to the $1 \mathrm{~mL}$ mark with more solvent mixture. The volumetric flask was tightly closed and shaken to ensure thorough mixing.

2.3.4.3. NMR spectroscopy. The NMR spectra were obtained on a Bruker Avance I $400 \mathrm{MHz}$ spectrometer. The solutions were analyzed using a $5 \mathrm{~mm}$ NMR tube.

The ${ }^{31} \mathrm{P}$ NMR spectra were obtained by the methods described by Granata and Argyropoulos, 1995 with a $5 \mathrm{~mm}$ QNP probe. More specifically, an observation sweep width of $6600 \mathrm{~Hz}$ was used, and the spectra were accumulated with a delay time of $25 \mathrm{~s}$ between successive pulses. All chemical shifts reported are relative to the reaction product of water with tetramethyldioxaphospholane, which has been observed to give a sharp signal in pyridine $/ \mathrm{CDCl}_{3}$ at $132.2 \mathrm{ppm}$. For each spectrum 512 scans were acquired; zero filling and decoupling were not used.

Semi-quantitative ${ }^{13} \mathrm{C}$ NMR spectra were recorded in the FT mode at $100.6 \mathrm{MHz}$ with a $5 \mathrm{~mm}$ Dual probe in acetone-d6. The inverse gated decoupling sequence, which allows quantitative analysis and comparison of signal intensities, was used with the following parameters: 90 pulse angle; $1.4 \mathrm{~s}$ acquisition time; $2 \mathrm{~s}$ relaxation delay; $64 \mathrm{~K}$ data points; and $30 \mathrm{~K}$ scans. Chromium(III) acetylacetonate $(0.01 \mathrm{M}$, Sigma) was added to the lignin solution to provide complete relaxation of all nuclei (Xia et al., 2001).

\subsubsection{FTIR}

FTIR spectra were recorded with a Nicolet 6700 FTIR spectrometer equipped with an ATR diamond single reflection crystal. All spectra were collected in absorbance in the $4000-700 \mathrm{~cm}^{-1}$ range.

\section{Results}

The extraction procedure was adapted from a published procedure (Pan et al., 2006). Pulping was performed at $160^{\circ} \mathrm{C}$ in batch reactor, pressure rising up to 10 bars. The ratio of solvent to straw was chosen to allow stirring of the mixture. In this study, six different Lewis acids have been investigated as catalysts for lignin extraction. The hardness of each acid was estimated with the Pearson model (Parr and Pearson, 1983), under the assumption that the metal was present in its cationic form in the aqueous ethanol solution. Anions from the Lewis acids were not considered for this hardness estimation. A wide range of Lewis acids were used with increasing and well spread values of hardness (Table 1). In the following study, the results will always be reported in order of increasing hardness of the cation: $\mathrm{FeCl}_{2}<\mathrm{CuCl}_{2}<\mathrm{FeCl}_{3}<\mathrm{Ga}(\mathrm{OTf})_{3}<\mathrm{ZrOCl}_{2}<\mathrm{Sc}(\mathrm{OTf})_{3}$. Triflate salts were used because of their higher activity than chlorides as Lewis acid catalysts in aqueous environment (Prakash et al., 2012).
An extraction catalysed by sulphuric acid was conducted as a reference procedure. Values of $\mathrm{pH}$ have been measured and found to be in the range 2.0-2.5 for the initial batch and 2.4-3.2 at the end of the extraction. The variation of the $\mathrm{pH}$ through the extraction process, due to the neutralisation of acid groups by straw fractions, was relatively limited due to the dilution of the straw in the system: the used solvent/straw mass ratio higher than 30 was higher than the ones used in other acid organosolv processes (Pan et al., 2005; Huijgen et al., 2011; Wildschut et al., 2013),

\subsection{Influence of the nature of the catalyst on yields and selectivities in lignin isolation.}

The degrees of straw delignification, the Klason lignin yields (Lks) and the distribution of phenolic compounds obtained with the different catalysts are reported in Table 1.

Two catalysts, $\mathrm{FeCl}_{2}$ and $\mathrm{CuCl}_{2}$, were less effective than $\mathrm{H}_{2} \mathrm{SO}_{4}$ and all the other systems gave quite the same degree of delignification, close to $80 \%$. The same trend was observed for the lignin yields (30\% for $\mathrm{FeCl}_{2}$ and $\mathrm{CuCl}_{2}$ and close to $40 \%$ for most other catalysts) suggesting an increase of the performance of the catalyst with the hardness of the Lewis acid. Ga(OTf $)_{3}$ exhibited a peculiar behaviour: with $62 \%$ yield and $78 \%$ selectivity, it was the most efficient system for the recovery of solid lignin. In most cases the selectivity to lignin represented around 50\% of the delignification products. The other phenolic products dissolved in the aqueous ethanol solution complete the mass balance. Gas chromatography coupled to mass spectrometry (GC/MS) analysis allowed to identify several aromatic monomers derived from the degradation of the main units of lignin $(G / S)$, namely 3-methoxy-4hydroxyacetophenone (a), 1,3-dimethoxy-2-hydroxybenzene (b), 2-methoxyphenol (c), 2,6-dimethoxy-1,4-benzoquinone (d), 2methoxy-4-vinylphenol (e), 3-methoxy-4-hydroxybenzaldehyde (f), 4-hydroxy-3,5-dimethoxybenzaldehyde (g), 4-hydroxy-3,5dimethoxyacetophenone (h) (Fig. 2).

However, these monomers were present in very low quantities, accounting for only $2 \%$ of the delignification products (Table 1 ). Whatever the catalyst, except $\mathrm{Ga}(\mathrm{OTf})_{3}$, around $47 \pm 2 \%$ of delignification products remained in the aqueous ethanol solution as soluble compounds and were analysed by size exclusion chromatography. The mass distribution evidenced molecular masses varying between 150 and $1500 \mathrm{~g} \mathrm{~mol}^{-1}$, which can be attributed to lignin-based monomers and oligomers up to hexamers or to corresponding lignin-carbohydrate complexes. The mass distribution spectra are reported in Supporting information, Fig. S1. The solubility of a fraction of lignin (Fig. S1) may have resulted in some lignin loss in the precipitation step, probably related to the dilution conditions used.

\subsection{Effect of the catalyst on lignin structures}

The effects of the Lewis acid extraction were evaluated by considering two different properties: the molar mass and the chemical structure.

\subsubsection{Molar mass and primary structure of the lignins}

The effects of each Lewis acid on the molar masses and polydispersity of lignins and acetylated lignins produced are reported in Table 2 (molar mass distributions of lignins and acetylated lignins are shown in Supporting information, Figs. S2 and S3). According to their nature and properties, lignins have different solubility in organic solvents. An incomplete solubility in the eluent is an additional source of error. To reduce errors, it is possible to acetylate lignins and improve their solubility in organic solvents (Baumberger et al., 2007). 
Table 2

Structural properties of lignins extracted with Lewis acids.

\begin{tabular}{|c|c|c|c|c|c|c|}
\hline \multirow[t]{2}{*}{ Catalyst } & \multicolumn{2}{|l|}{ Lignin } & \multicolumn{2}{|c|}{ Acetylated lignin } & \multicolumn{2}{|l|}{ Thioacidolysis } \\
\hline & $\operatorname{Mw}\left(\mathrm{g} \mathrm{mol}^{-1}\right)$ & $\mathrm{Mw} / \mathrm{Mn}$ & $\mathrm{Mw}\left(\mathrm{g} \mathrm{mol}^{-1}\right)$ & $\mathrm{Mw} / \mathrm{Mn}$ & $\beta-\mathrm{O}-4\left(\mu \mathrm{molg}^{-1} \mathrm{Kls}\right)$ & $S / G(\beta-0-4)$ \\
\hline Straw & 1 & 1 & 1 & 1 & 1150 & 1.02 \\
\hline $\mathrm{H}_{2} \mathrm{SO}_{4}$ & 5300 & 1.8 & 8000 & 1.6 & 670 & 0.67 \\
\hline $\mathrm{FeCl}_{2}$ & 5800 & 1.9 & 7000 & 2.1 & 260 & 0.9 \\
\hline $\mathrm{CuCl}_{2}$ & 8300 & 1.7 & 9500 & 2.2 & 180 & 0.86 \\
\hline $\mathrm{FeCl}_{3}$ & 5100 & 1.8 & 9500 & 1.9 & 260 & 0.94 \\
\hline $\mathrm{Ga}(\mathrm{OTf})_{3}$ & 3300 & 1.6 & 4600 & 1.4 & 0 & n.a. \\
\hline $\mathrm{ZrOCl}_{2}$ & 4700 & 1.7 & 6000 & 1.5 & 70 & 0.74 \\
\hline $\mathrm{Sc}(\mathrm{OTf})_{3}$ & 3800 & 1.7 & 4400 & 1.4 & 10 & 0.86 \\
\hline
\end{tabular}

The average molecular masses of the lignins were in the range $3000-8000 \mathrm{~g} \mathrm{~mol}^{-1}$ for non acetylated lignins and $4000-9500 \mathrm{~g} \mathrm{~mol}^{-1}$ for acetylated lignins, which is higher than masses, found in other organosolv lignins (Arshanitsa et al., 2013). The lowest masses were observed for the lignin obtained from treatment with gallium triflate and scandium triflate. Conversely, copper chloride provided the highest molecular mass of lignin and acetylated lignins. Most of the harder Lewis acids $\left(\mathrm{Ga}(\mathrm{OTf})_{3}, \mathrm{ZrOCl}_{2}\right.$, $\left.\mathrm{Sc}(\mathrm{OTf})_{3}\right)$ produced lignins with the smallest molecular masses. Surprisingly, the precipitated lignin obtained with $\mathrm{Ga}(\mathrm{OTf})_{3}$ is not soluble in the aqueous-ethanol liquor despite its low molecular weight. The nature of the functional groups of this particular lignin is probably responsible for the low solubility. The polydispersity indexes of all the lignins produced lie around 1.7 (1.6-1.9) and, in the case of the acetylated lignins, were in the range 1.4-2.2.

In order to get some insight about the primary structure of lignins, the frequency of $\beta$-aryl ether bonds $(\beta-0-4)$ in the lignin has been determined by analysis of the thioacidolysis products. This method also allowed the ratio between syringyl and guaiacyl units linked by the $\beta-0-4$ linkages $(S / G)$ to be calculated.

The quantities of cleaved $\beta-\mathrm{O}-4$ links, expressed in $\mu \mathrm{mol} \mathrm{g}^{-1}$ of Klason lignin, in the lignins extracted with the different Lewis acids are reported in Table 2 . In the initial wheat straw $1150 \mu \mathrm{mol} \mathrm{g}^{-1}$ of $\beta-\mathrm{O}-4$ bonds were measured, in good agreement with previous reports (Lapierre et al., 1989, 1988). After treatment with sulphuric acid, the number of $\beta-0-4$ links decreased to $650 \mu \mathrm{mol} \mathrm{g}^{-1}$, corresponding to around one $\beta-0-4$ link per 10 phenolic units. The action of the Lewis acids further lowered the amount of $\beta-0-4$ bonds, which decreased to $10 \mu \mathrm{molg}^{-1}$ with $\mathrm{Sc}(\mathrm{OTf})_{3}$ and even below detectable levels with $\mathrm{Ga}(\mathrm{OTf})_{3}$. A progressive decrease in the quantity of $\beta$-aryl ether links is observed while the hardness of the Lewis acid increases, $\mathrm{Ga}(\mathrm{OTf})_{3}$ having an extreme behaviour also on this account.

The decrease of $\beta-0-4$ bonds in acid-catalyzed organosolv treatment can be related to a significant decrease of $\beta$-aryl ethers observed in the hydrothermal treatment of wheat straw without addition of acids (Yelle et al., 2013). No comparable decrease of $\beta-0-4$ bonds is observed in milling, alkaline or enzymatic treatment of wheat straw (Billa and Monties, 1995).

The $S / G$ ratio of the $\beta-0-4$ bonds in the initial straw was 1.02 and in all acid-treated lignins this value was lower. However, for all the Lewis acid-treated lignins, the ratio was much higher than for the $\mathrm{H}_{2} \mathrm{SO}_{4}$-issued lignin. This preferential cleavage of the $\beta-\mathrm{O}-4$ bonds connected to syringyl units was not observed for milder straw treatments (Billa and Monties, 1995) but was observed for lignin issued from straw oxidative treatments (Lequart et al., 1998).

\subsubsection{Chemical structure by NMR spectroscopies}

3.2.2.1. ${ }^{31} N M R$ spectroscopy. All precipitated lignins were studied by quantitative ${ }^{31} \mathrm{P}$ NMR analyses after phosphorylation with 2-chloro-4,4,5,5-tetramethyl-1,3,2-dioxaphospholane in the presence of a known amount of cyclohexanol as internal standard (Table 3). Spectra and attributions are reported in Supporting information, Figs. S4 and S5. Residual metal from the catalyst in the case of $\mathrm{CuCl}_{2}, \mathrm{FeCl}_{2}$ and $\mathrm{ZrOCl}_{2}$ did not allow proper quantitative NMR analyses.

Recently, Arshanitsa et al., 2013 published a ${ }^{31} \mathrm{P}$ NMR study on an organosolv wheat straw lignin obtained by CIMV process and Huijgen et al., 2014 reported a study on wheat straw lignins resulting from $\mathrm{H}_{2} \mathrm{SO}_{4}$ organosolv treatment. In table 3, the amount of $p$-hydroxyphenyl, guaiacyl and syringyl units of lignin resulting from $\mathrm{H}_{2} \mathrm{SO}_{4}$ treatment are slightly different from pre-<smiles>COc1cc(C(C)=O)ccc1O</smiles>

a<smiles>C=Cc1ccc(O)c(OC)c1</smiles>

e<smiles>COc1cccc(OC)c1O</smiles>

b<smiles>COc1ccccc1O</smiles>

c<smiles>COC1=CC(=O)C=C(OC)C1=O</smiles>

d

Fig. 2. Identified monomers in aqueous ethanol solution during catalytic lignin extraction. 
Table 3

${ }^{31}$ P NMR spectral data for hydroxyl contents.

\begin{tabular}{|c|c|c|c|c|}
\hline \multirow[t]{2}{*}{ Assignment } & \multicolumn{4}{|c|}{ Lignin sample } \\
\hline & $\mathrm{H}_{2} \mathrm{SO}_{4}$ & $\mathrm{FeCl}_{3}$ & $\mathrm{Ga}(\mathrm{OTf})_{3}$ & $\mathrm{Sc}(\mathrm{OTf})_{3}$ \\
\hline $\mathrm{OH}_{\text {aliphatic }}$ content, mmol g ${ }^{-1}$ & 1.82 & 2.01 & 1.62 & 1.55 \\
\hline $\mathrm{OH}_{\text {phenolic }}$ content in condensed substructures ${ }^{\mathrm{a}}, \mathrm{mmol} \mathrm{g}^{-1}$ & 0.93 & 0.86 & 0.9 & 0.9 \\
\hline $\mathrm{OH}_{\text {phenolic }}$ content in syringyl substructures, $\mathrm{mmol} \mathrm{g}^{-1}$ & 0.58 & 0.48 & 0.48 & 0.5 \\
\hline $\mathrm{OH}_{\text {phenolic }}$ content in guaiacyl, $\mathrm{mmol} \mathrm{g}^{-1}$ & 0.64 & 0.6 & 0.49 & 0.49 \\
\hline $\mathrm{OH}_{\text {phenolic }}$ content in p-hydroxyphenyl substructures, mmol g ${ }^{-1}$ & 0.2 & 0.19 & 0.17 & 0.15 \\
\hline Total $\mathrm{OH}_{\text {phenolic }}$ content, mmol g-1 & 2.35 & 2.13 & 2.05 & 2.03 \\
\hline $\mathrm{COOH}, \mathrm{mmolg}^{-1}$ & 0.09 & 0.07 & 0.11 & 0.11 \\
\hline Total $\mathrm{OH}$ groups content, $\mathrm{mmol} \mathrm{g}^{-1}$ & 4.26 & 4.21 & 3.77 & 3.69 \\
\hline $\mathrm{S} / \mathrm{G}$ ratio & 0.89 & 0.8 & 0.98 & 1.01 \\
\hline
\end{tabular}

a Biphenyl-, diphenylether and diphenylmethane substructures.

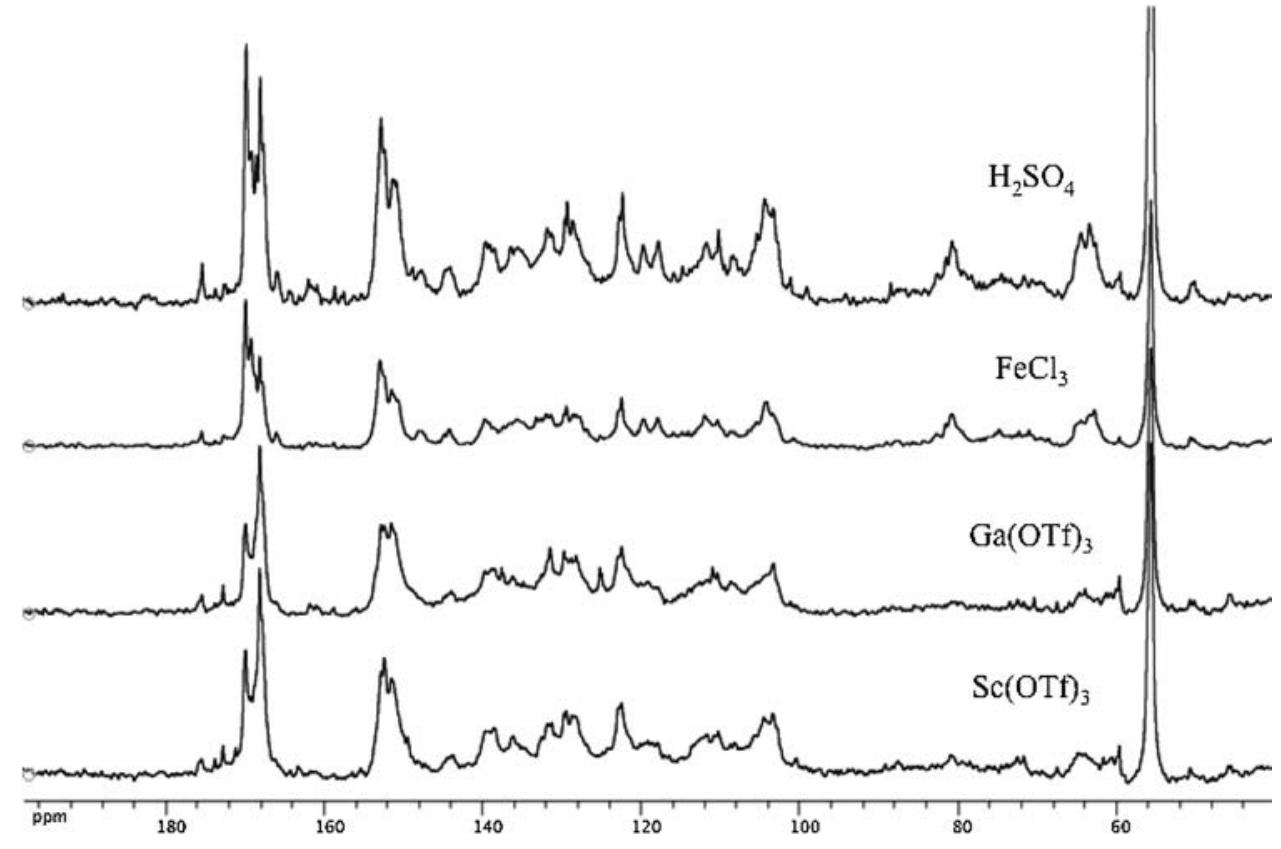

Fig. 3. Quantitative ${ }^{13} \mathrm{C}$ NMR spectra of the different lignin fractions.

vious studies. The $H / G / S$ ratio is $14 / 45 / 41$ in our case is more similar to the ratio $14 / 38 / 48$ obtained in wheat dioxane lignin (Kanitskaya et al., 1998) than to the ratios obtained in more severe acid treatments, like the 22/54/31 ratio in wheat CIMV lignin (Arshanitsa et al., 2013), the 25/51/24 ratio in wheat aqueous ethanol lignin catalysed by $15 \mathrm{mmol} / \mathrm{L} \mathrm{H}_{2} \mathrm{SO}_{4}$ (Huijgen et al., 2014) or the traces $/ 67 / 32$ ratio from aqueous ethanol treatment catalysed by $2 \mathrm{~mol} / \mathrm{L} \mathrm{H}_{2} \mathrm{SO}_{4}$ (Heiss-Blanquet et al., 2011). Also the amount of carboxylic acid groups in our aqueous ethanol lignin catalysed by $4 \mathrm{mmol} / \mathrm{L} \mathrm{H}_{2} \mathrm{SO}_{4}\left(0.09 \mathrm{mmol} \mathrm{g}^{-1}\right)$ is lower than the values previously measured in CIMV lignin $\left(0.69 \mathrm{mmol} \mathrm{g}^{-1}\right)$ (Arshanitsa et al., 2013) and $0.43 \mathrm{mmol} \mathrm{g}^{-1}$ reported in wheat aqueous ethanol lignin catalysed by $15 \mathrm{mmol} / \mathrm{L} \mathrm{H}_{2} \mathrm{SO}_{4}$ (Huijgen et al., 2014).

3.2.2.2. ${ }^{13} \mathrm{NMR}$ spectroscopy. Fig. 3 summarises the ${ }^{13} \mathrm{C}$ NMR spectral data acquired for $\mathrm{H}_{2} \mathrm{SO}_{4}, \mathrm{FeCl}_{3}, \mathrm{Ga}(\mathrm{OTf})_{3}$ and $\mathrm{Sc}(\mathrm{OTf})_{3}$ organosolv lignin. Attributions are based on previously published results (Ralph and Landucci 2010; Ralph et al., 2004; Zeng et al., 2013).

Table 4

Assignment and integration of ${ }^{13} \mathrm{C}$ NMR spectra as equivalents per average aromatic ring.

\begin{tabular}{|c|c|c|c|c|c|}
\hline Spectroscopic range $(\delta, \mathrm{ppm})$ & Assignment & $\mathrm{H}_{2} \mathrm{SO}_{4}$ & $\mathrm{FeCl}_{3}$ & $\mathrm{Ga}(\mathrm{OTf})_{3}$ & $\mathrm{Sc}(\mathrm{OTf})_{3}$ \\
\hline $172-169.9$ & Aliphatic $\mathrm{AcC}=\mathrm{O}$ & 0.54 & 0.81 & 0.32 & 0.44 \\
\hline $169.3-168.2$ & Phenolic $A c C=0$ & 0.4 & 0.4 & 0.41 & 0.68 \\
\hline $156-142$ & Aromatic $\mathrm{C}-\mathrm{O}$ bond & 1.54 & 1.61 & 1.45 & 1.46 \\
\hline $142-125$ & Aromatic $\mathrm{C}-\mathrm{C}$ bond & 1.94 & 1.98 & 2.21 & 2.08 \\
\hline $125-101$ & Aromatic $\mathrm{C}-\mathrm{H}$ bond & 2.59 & 2.52 & 2.44 & 2.58 \\
\hline $114-110$ & C2 in Gunits & 0.64 & 0.46 & 0.36 & 0.39 \\
\hline $108-103$ & $\mathrm{C} 2,6$ in $\mathrm{S}$ units & 0.75 & 0.7 & 0.57 & 0.62 \\
\hline $76-74$ & $\mathrm{C} \alpha$ in $\beta-\mathrm{O}-4$ & 0.14 & 0.23 & 0.02 & 0.04 \\
\hline $89.5-87.5$ & $\mathrm{C} \alpha$ in $\beta-5$ & 0.05 & 0.05 & 0 & 0 \\
\hline $87-86$ & $C \alpha$ in $\beta-\beta$ & 0.03 & 0.02 & 0 & 0 \\
\hline $90-72$ & Aliphatic $\mathrm{CH}-\mathrm{O}-$ & 1.06 & 0.62 & 0.49 & 0.42 \\
\hline $72-59$ & Aliphatic $\mathrm{CH}_{2}-\mathrm{O}-$ & 1.03 & 0.52 & 0.57 & 0.41 \\
\hline $58-55$ & Methoxyl $\mathrm{OCH}_{3}$ & 1.12 & 1.28 & 0.82 & 1.02 \\
\hline
\end{tabular}


Table 5

Lignin structural characteristics calculated from ${ }^{13} \mathrm{C}$ NMR Spectra.

\begin{tabular}{lcccc}
\hline & $\mathrm{H}_{2} \mathrm{SO}_{4}$ & $\mathrm{FeCl}_{3}$ & $\mathrm{Ga}(\mathrm{OTf})_{3}$ & $\mathrm{Sc}(\mathrm{OTf})_{3}$ \\
\hline Aliphatic etherified C/Aromatic C & 0.34 & 0.19 & 0.17 & 0.14 \\
S units & 0.38 & 0.35 & 0.28 & 0.31 \\
G units & 0.64 & 0.46 & 0.36 & 0.39 \\
S/Gratio & 0.6 & 0.8 & 0.8 & 0.8 \\
Condensation (\%) & 41 & 48 & 56 & 42 \\
\hline
\end{tabular}

The lignin ${ }^{13} \mathrm{CNMR}$ spectra (Fig. 3 ) were integrated by setting the area of the aromatic region ( $\delta 154-106 \mathrm{ppm}$ ) equal to 6.12 , assuming that it includes contributions from 6 aromatic carbons and 0.12 vinylic carbons (Capanema et al., 2004). Therefore, all other functional group results are reported as equivalences per aromatic ring (equiv/Ar) in Table 4. The number of methoxyl carbons per aromatic ring is 1.12 for the $\mathrm{H}_{2} \mathrm{SO}_{4}$-lignin. This value is changing according to the catalyst, with a maximum of 1.28 for $\mathrm{FeCl}_{3}$ and a minimum of 0.82 for $\mathrm{Ga}(\mathrm{OTf})_{3}$. Demethylation of aromatic ring may occur by hydrolytic cleavage of $\mathrm{C}-\mathrm{O}$ bounds with water-tolerant Lewis acids (Yang et al., 2014), and could explain a bias in G units quantification by ${ }^{31} \mathrm{P}$ NMR spectroscopy (Argyropoulos, 1995). The syringyl/guaiacyl ratio $(\mathrm{S} / \mathrm{G})$ was calculated on the basis of the number of carbons per aromatic ring in C2 for guaiacyl and C2 and C6 for syringyl units (Capanema et al., 2005). The integral value between $\delta 108$ and 103 ppm divided by 2 can then be used to estimate the content of syringyl moieties, and the guaiacyl moieties were determined by the integral value between $\delta 114$ and $110 \mathrm{ppm}$. No $\mathrm{H}$ units were detected by ${ }^{13} \mathrm{C}$ NMR at $\delta 158-156(\mathrm{H}-4)$. The results reported in Table 5 indicate a lower $\mathrm{S} / \mathrm{G}$ ratio for $\mathrm{H}_{2} \mathrm{SO}_{4}$ treated lignin than for the Lewis acid-treated ones, in good agreement with the results of thioacidolysis. However, it is noteworthy to mention that both $\mathrm{S}$ and $\mathrm{G}$ lignin contents are lower for Lewis acid-treated samples than for the $\mathrm{H}_{2} \mathrm{SO}_{4}$-treated lignin. The decrease is probably due to condensation reactions occurring on $\mathrm{C} 2, \mathrm{C} 5$, or $\mathrm{C} 6$ of the aromatic ring of lignin, resulting in the formation of new structures that shift these signals downfield (Hallac et al., 2010).

The aliphatic region (90-59 ppm) of the ${ }^{13} \mathrm{C}$ NMR spectra displays signals because of the aliphatic $\mathrm{C}-\mathrm{O}$ bonds implying $\alpha, \beta$ and $\gamma$ carbons on the lignin side-chain. $\beta-\mathrm{O}-4$ linkages $(\mathrm{C} \alpha$ at $\delta$ $76-74 \mathrm{ppm})$ were present in small amount in the $\mathrm{H}_{2} \mathrm{SO}_{4}(0.14 / \mathrm{Ar})$ and $\mathrm{FeCl}_{3}(0.23 / \mathrm{Ar})$ lignin, and absent in $\mathrm{Ga}(\mathrm{OTf})_{3}$ and $\mathrm{Sc}(\mathrm{OTf})_{3}$ lignin. $C \alpha$ of $\beta-5$ and $\beta-\beta$ bonds can be identified in the regions $79.5-77.5$ and $77-76 \mathrm{ppm}$, and were quantified as 0.14 and $0.05 / \mathrm{Ar}$ in $\mathrm{H}_{2} \mathrm{SO}_{4}$; and 0.23 and $0.05 / \mathrm{Ar}$ in $\mathrm{FeCl}_{3}$, respectively, while these structures were not observed for the Ga- and Sc-treated samples.

The aromatic region of the ${ }^{13} \mathrm{C}$ NMR spectrum can be subdivided into three regions of interest, which provide additional information on the lignin structure. These are the protonated aromatic $(\delta 125-101 \mathrm{ppm})$, the condensed aromatic $(\delta 142-125 \mathrm{ppm})$ and the oxygenated aromatic ( $\delta 154-142 \mathrm{ppm})$ regions (Ralph and Landucci, 2010). The oxygenated aromatic region contains mainly the $\mathrm{C} 3$ and $\mathrm{C} 4$ carbons on the aromatic ring for $\mathrm{G}$ units (plus C5 for $\mathrm{S}$ units). The condensed aromatic region consists of $\mathrm{C} 1$ carbons plus any ring carbons involved in cross-linking, such as the $5-5$ or $\beta-\beta$ substructures present in lignin. The protonated aromatic region comprises $\mathrm{C} 2, \mathrm{C} 6$, and any uncondensed $\mathrm{C} 5$ carbons. Because the oxygenated aromatic and condensed aromatic regions have some degree of overlapping, calculation of the degree of condensation is less precise when using these regions (Holtman et al., 2006). However, a comparison of the integration values of these three regions can provide some information on the degree of condensation of the lignin fractions. Within the aromatic region, the proportion of oxygenated aromatic carbons is lower in $\mathrm{Ga}(\mathrm{OTf})_{3}$ and $\mathrm{Sc}(\mathrm{OTf})_{3}$ compared to $\mathrm{H}_{2} \mathrm{SO}_{4}$ and $\mathrm{FeCl}_{3}$. The degree of condensation of the lignin structure is calculated as 3 - the total area of the protonated aromatic region and is expressed in Table 5.

\subsubsection{Chemical structure of lignin by FT-IR spectroscopy}

Fig. 4 shows the infrared spectra between 1800 and $700 \mathrm{~cm}^{-1}$ of the different lignins. They were classified in relation to the hardness of the Lewis acid used for the extraction (the softest acid at the top and the hardest at the bottom). The spectra have been normalised to allow comparison and, for sake of clarity, the curves have been placed at equal intervals on the $y$-axis.

All the infrared spectra are characteristic of lignins. According to the characterization of Faix, 1991, the presence of an absorbance peak at $1220 \mathrm{~cm}^{-1}$, along with the conjugated ester band around $1160 \mathrm{~cm}^{-1}$, corresponds to HGS type lignins; which contain at the same time syringyl, guaiacyl and $p$-hydroxyphenyl units. The relative intensity of the bands around 1120 and $1710 \mathrm{~cm}^{-1}$ is typical for organosolv-extracted lignins (Tejado et al., 2007). The attribution of the bands and their relative absorbance for each lignin are presented in Table 6.

The most intense bands of the precipitated lignin formed in the presence of $\mathrm{CuCl}_{2}$ vibrate at 1036 and $1051 \mathrm{~cm}^{-1}$ and are clearly not lignin-related, like relatively weak bands at 1539 and $1736 \mathrm{~cm}^{-1}$. These bands are typical of organosolv hemicelluloses and the $\mathrm{C}=\mathrm{O}$

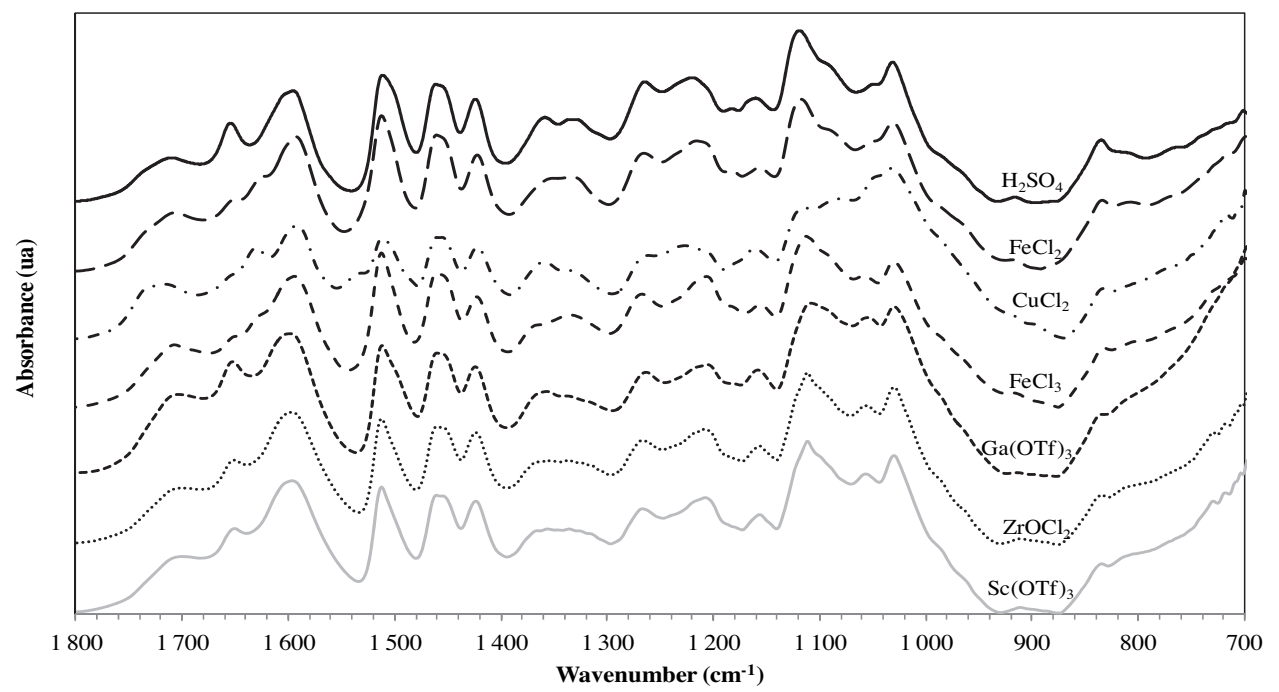

Fig. 4. Infrared spectra of the precipitated lignins. 
Table 6

Attributions and relative absorbance of the infrared bands for the various precipitated lignins.

\begin{tabular}{|c|c|c|c|c|c|c|c|c|}
\hline & \multirow[b]{2}{*}{$\mathrm{cm}^{-1}$} & \multicolumn{7}{|c|}{ Relative absorbances } \\
\hline & & $\mathrm{H}_{2} \mathrm{SO}_{4}$ & $\mathrm{FeCl}_{2}$ & $\mathrm{CuCl}_{2}$ & $\mathrm{FeCl}_{3}$ & $\mathrm{Ga}(\mathrm{OTf})_{3}$ & $\mathrm{ZrOCl}_{2}$ & $\mathrm{Sc}(\mathrm{OTf})_{3}$ \\
\hline \multirow[t]{2}{*}{$v \mathrm{C}=\mathrm{O}$ non-conjugated } & 1736 & & & 0.29 & & & & \\
\hline & $1714-1707$ & 0.26 & 0.33 & 0.32 & 0.36 & 0.47 & 0.32 & 0.33 \\
\hline \multirow{2}{*}{$v \mathrm{C}=\mathrm{O}$ conjugated } & $1657-1654$ & 0.45 & 0.4 & 0.36 & 0.41 & 0.66 & 0.49 & 0.48 \\
\hline & $1634-1628$ & & 0.53 & 0.52 & 0.53 & & & \\
\hline \multirow[t]{2}{*}{$v \mathrm{C}=\mathrm{C}$ aromatic } & $1602-1595$ & 0.64 & 0.77 & 0.66 & 0.75 & 0.83 & 0.76 & 0.77 \\
\hline & 1539 & & & 0.37 & & & & \\
\hline$\nu \mathrm{C}=\mathrm{C}$ aromatic & $1515-1513$ & 0.73 & 0.89 & 0.58 & 0.9 & 0.75 & 0.72 & 0.73 \\
\hline$\delta$ asym, $\mathrm{C}-\mathrm{H}$ en $\mathrm{CH}_{2}, \mathrm{CH}_{3}$ & 1462 & 0.69 & 0.78 & 0.59 & 0.78 & 0.7 & 0.69 & 0.69 \\
\hline$v \mathrm{C}=\mathrm{C}$ aromatic & 1425 & 0.6 & 0.67 & 0.54 & 0.64 & 0.62 & 0.64 & 0.64 \\
\hline$\delta \mathrm{C}-\mathrm{H}$ in $\mathrm{CH}_{3}$ or & $1371-1361$ & 0.49 & 0.52 & 0.44 & 0.47 & 0.49 & 0.48 & 0.47 \\
\hline \multicolumn{9}{|l|}{$\delta \mathrm{O}-\mathrm{H}$ phenolic } \\
\hline$v \mathrm{C}-\mathrm{O}$ syringyl unit & $1340-1335$ & 0.48 & 0.54 & 0.4 & 0.54 & 0.47 & 0.49 & 0.48 \\
\hline$\delta \mathrm{O}-\mathrm{H}$ secondary alcohols & $1321-1317$ & & & & & 0.45 & 0.47 & 0.47 \\
\hline$v \mathrm{C}-\mathrm{O}$ guaiacyl unit & $1271-1267$ & 0.69 & 0.67 & 0.48 & 0.65 & 0.6 & 0.6 & 0.6 \\
\hline$v \mathrm{C}-\mathrm{O}$ phenolic $\mathrm{OH}$ or ethers & $1232-1218$ & 0.72 & 0.75 & 0.54 & 0.72 & 0.62 & 0.64 & 0.65 \\
\hline \multirow[t]{2}{*}{$v \mathrm{C}-\mathrm{O}$ diphenylethers } & 1209 & & 0.75 & 0.52 & 0.76 & 0.64 & 0.67 & 0.69 \\
\hline & $1186-1181$ & 0.54 & 0.58 & 0.44 & 0.6 & & & \\
\hline$v \mathrm{C}-\mathrm{O}$ conjugated esters & $1164-1156$ & 0.6 & 0.59 & 0.52 & 0.59 & 0.6 & 0.56 & 0.6 \\
\hline$\delta \mathrm{C}-\mathrm{H}$ in-plane aromatic syringyl and guaiacyl & $1121-1119$ & 1.00 & 1.00 & 0.75 & & & & \\
\hline$\delta \mathrm{C}-\mathrm{H}$ in-plane aromatic syringyl & $1114-1111$ & & & & 1.00 & 1.00 & 1.00 & 1.00 \\
\hline \multirow[t]{2}{*}{$v \mathrm{C}-\mathrm{O}$ secondary alcohols \& aliphatic esters } & $1102-1087$ & 0.82 & 0.83 & 0.82 & 0.9 & 0.98 & 0.91 & 0.92 \\
\hline & $1062-1051$ & 0.68 & 0.74 & 0.94 & 0.76 & 0.92 & 0.8 & 0.8 \\
\hline$\delta \mathrm{C}-\mathrm{H}$ aromatics. $v \mathrm{C}-\mathrm{O}$ primary alcohols $\& v \mathrm{C}=\mathrm{O}$ non-conjugated & $1036-1031$ & 0.81 & 0.86 & 1 & 0.84 & 0.98 & 0.91 & 0.92 \\
\hline$\delta \mathrm{C}-\mathrm{H}$ out of plane $1,2,4$ substituted aromatics & $921-914$ & 0.02 & 0.06 & 0.02 & 0.09 & 0.02 & 0.04 & 0.03 \\
\hline$\delta \mathrm{C}-\mathrm{H}$ out of plane $1,2,4$ substituted aromatics & 902 & & & & & 0.02 & 0.03 & 0.03 \\
\hline$\delta \mathrm{C}-\mathrm{H}$ out of plane tetrasubstituted aromatics & $839-836$ & 0.35 & 0.4 & 0.29 & 0.33 & 0.36 & 0.28 & 0.27 \\
\hline
\end{tabular}

stretching of carboxyl group at $1736 \mathrm{~cm}^{-1}$ indicate the presence of esterified uronic acid residues (Xu et al., 2006). The incomplete cleavage of polysaccharide units from lignin is a further confirmation of the low delignification level that can be attained with the least strong Lewis acids (see Table 1). Moreover, the increase of the intensity of the bands related to primary and secondary hydroxyls with the hardness of the Lewis acid is in good agreement with the level of sugar units measured after Klason treatment of the precipitated lignins (see Table S1).

Other analytical differences induced by different hardness of the Lewis acids can be observed. The harder the Lewis acid, the more intense the bands of aliphatic alcohols around 1320, 1100 and $1035 \mathrm{~cm}^{-1}$. Interestingly, for all lignins issued from Lewis acid treatments the bands attributed to aliphatic alcohols were more intense than for the $\mathrm{H}_{2} \mathrm{SO}_{4}$-issued lignin.

The lignin formed in the presence of $\mathrm{Ga}(\mathrm{OTf})_{3}$ differs slightly from the other lignins. On one hand, it shows the same high amount of aliphatic alcohols observed with the other hard Lewis acids. On the other hand, it produces particularly intense bands at 1706 and $1657 \mathrm{~cm}^{-1}$ and between 1096 and $1033 \mathrm{~cm}^{-1}$, suggesting the presence of a higher fraction of esterified acid groups.

Also observed at increasing strength of the Lewis acids is an increase in the frequency of vibrations of the ester conjugates to $1160 \mathrm{~cm}^{-1}$ (Bayerbach and Meier, 2009) and a systematic shift to lower frequencies of the band between 1121 and $1114 \mathrm{~cm}^{-1}$, due to in-plane deformation of aromatic $\mathrm{C}-\mathrm{H}$ bonds. This last phenomenon has been interpreted by Faix, 1991 and Tejado et al., 2007 as a reduction in the ratio between syringyl and guaiacyl units. Moreover, the shift of the main band of out-of-plane vibration of the aromatic $\mathrm{C}-\mathrm{H}$ bonds from 920 to $837 \mathrm{~cm}^{-1}$ corresponds to the shift from trisubstituted to tetrasubstituted aromatics (Socrates, 2001).

\section{Discussion}

The nature of the Lewis acid catalysts induces important changes in the yield of precipitated lignin. In most cases, the process leads to the formation of a large amount of soluble phenolic-derived oligomers. The valourisation of this kind of oligomers is worth to study as a significant asset of reactive extraction processes in the presence of Lewis acids. Another potential asset is represented by the range of lignins with different structural properties that can be obtained.

Indeed, the use of Lewis acid catalysts induces significant variations with respect to the results obtained by delignification with $\mathrm{H}_{2} \mathrm{SO}_{4}$. The most striking effect is the cleavage of $\beta-0-4$ linkages during delignification with the hardest Lewis acids. This is consistent with the acid-catalyzed scission of $\beta$-ether and $\alpha$-ether linkages, which has been proposed as the major mechanism of lignin dissolution in acidic organosolv systems (McDonough, 1993). The cleavage of ether linkages is responsible for lignin breakdown in organosolv pre-treatment. Condensation is increasing as aliphatic $\mathrm{C}-\mathrm{O}$ bond content is decreasing, except for $\mathrm{Sc}(\mathrm{OTf})_{3}$ lignin. This effect is compatible with $\beta$-ether and $\alpha$-ether linkages cleavage. In the case of $\mathrm{Sc}(\mathrm{OTf})_{3}$ lignin, a weak condensation associated with a weak $\mathrm{C}-\mathrm{O}$ bond content may be due to the formation of Hibbert's ketone-type structures (Bauer et al., 2012). However, the increase in condensation is weak and cannot compensate the total breaking of aryl-ether bonds in the case of $\mathrm{Ga}(\mathrm{OTf})_{3}$ and $\mathrm{Sc}(\mathrm{OTf})_{3}$ lignins. Other multidimensional NMR studies should be done in order to explain the possible formation of new structures such as isochroman or C2/C6 condensed moieties (McDonough, 1993; Peng et al., 1998).

It is interesting to compare the results of NMR spectroscopy with the results of infrared spectroscopy, a technique which, despite some complexity of interpretation, allows an analysis of the chemical structure and functionalization of samples without any chemical modification. The indication by IR spectroscopy of a lower $S / G$ ratio at higher hardness of the Lewis acid is apparently contradictory with the increase of S/G ratio with Lewis acid strength observed by ${ }^{13} \mathrm{C}$ and ${ }^{31} \mathrm{P}$ NMR spectroscopy. This discrepancy is of difficult interpretation. It seems not to depend on the difficulty of interpretation of the IR spectra, as some of the IR data are outside the crowded spectral region of $\mathrm{C}-\mathrm{H}$ bending and $\mathrm{C}-\mathrm{O}$ stretching vibrations, in which attributions are at a large extent empirical. On the other side, ${ }^{31} \mathrm{P}$ NMR spectroscopy of phosphorylated moieties provides information only on the nature of the $\mathrm{OH}$ group present 
in the molecule and does not provide any information on etherified phenolic groups. However, ${ }^{13} \mathrm{C}$ NMR and infrared spectra have been nominally measured on the same specimens.

Nevertheless, the use of complementary techniques allows a better understanding of the results of each of the characterization methods. It seems likely that advanced modelisation of the NMR and IR spectra of models of lignin is needed to solve this quandary.

Under several aspects, lignins isolated in the presence of Lewis acids are similar to other organosolv lignins. However, they present a striking difference from other lignins: a spectacular decrease of aryl ether bonds, shown by thioacidolysis and confirmed by spectroscopic methods.

\section{Conclusions}

Lewis acids have been studied as catalysts in the organosolv treatment of wheat straw. Hard Lewis acids allow to obtain a greater degree of delignification and a yield of Klason lignin greater than that achieved with sulphuric acid. This process leads also to the formation of aromatic monomers in very small amount, and a significant amount of soluble phenolic-derived oligomers, issued from delignification process. According to the chosen catalyst, the lignins extracted from the same lignocellulosic resource present different structural and chemical properties allowing different reactivities to be expected in further chemical reactions.

\section{Acknowledgements}

Sebastião Braz de la Faria Junior is thanked for his participation to the project. The authors are grateful to the ANR Carnot Institute CED2, the INRA-CNRS GDR Biomatpro for financial support. The author would like to thank the MENESR, the ENSCM, the CNRS and the INRA for supporting this work.

\section{References}

Argyropoulos, D.S., 1995. P-31 NMR in wood chemistry - a review of recent progress. Res. Chem. Intermed. 21, 373-395.

Arshanitsa, A., Ponomarenko, J., Dizhbite, T., Andersone, A., Gosselink, R.J.A., van der Putten, J., Lauberts, M., Telysheva, G., 2013. Fractionation of technical lignins as a tool for improvement of their antioxidant properties. J. Anal. Appl. Pyrol. 103, 78-85.

Bauer, S., Sorek, H., Mitchell, V.D., Ibanez, A.B., Wemmer, D.E., 2012. Characterization of miscanthus giganteus lignin isolated by ethanol organosolv process under reflux condition. J. Agric. Food Chem. 60, 8203-8212.

Baumberger, S., Abaecherli, A., Fasching, M., Gellerstedt, G., Gosselink, R., Hortling, B., Li, J., Saake, B., de Jong, E., 2007. Molar mass determination of lignins by size-exclusion chromatography: towards standardisation of the method. Holzforschung 61, 459-468.

Bayerbach, R., Meier, D., 2009. Characterization of the water-insoluble fraction from fast pyrolysis liquids (pyrolytic lignin). Part IV: structure elucidation of oligomeric molecules. J. Anal. Appl. Pyrol. 85, 98-107.

Berlin, A., Balakshin, M.Y., Ma, R., Maximenko, G.V., Ortiz, D., 2013. Organosolv process EP2588664.

Billa, E., Monties, B., 1995. Molecular variability of lignin fractions-isolated from wheat-straw. Res. Chem. Intermed. 21, 303-311.

Capanema, E.A., Balakshin, M.Y., Kadla, J.F., 2004. A comprehensive approach fo quantitative lignin characterization by NMR spectroscopy. J. Agric. Food Chem. 52, 1850-1860.

Capanema, E.A., Balakshin, M.Y., Kadla, J.F., 2005. Quantitative characterization of a hardwood milled wood lignin by nuclear magnetic resonance spectroscopy. J. Agric. Food Chem. 53, 9639-9649.

Faix, O., 1991. Classification of lignins from differents botanical origins by FT-IR spectroscopy. Holzforschung 45, 21-27.
Gösta, B., Knut, L., 2010. Lignin and Lignans. In: Heitner, C., Dimmel, D.R., Schmidt, J.A. (Eds.), Advances in Chemistry. CRC Press, Boca Raton, USA, pp. 267-299. Granata, A., Argyropoulos, D.S., 1995.

2-Chloro-4,4,5,5-tetramethyl-1,3,2-dioxaphospholane, a reagent for the accurate determination of the uncondensed and condensed phenolic moieties in lignins. J. Agric. Food Chem. 43, 1538-1544.

Hallac, B.B., Pu, Y., Ragauskas, A.J., 2010. Chemical transformations of buddleja davidii lignin during ethanol organosolv pretreatment. Energy Fuels 24, 2723-2732

Heiss-Blanquet, S., Zheng, D., Lopes Ferreira, N., Lapierre, C., Baumberger, S., 2011. Effect of pretreatment and enzymatic hydrolysis of wheat straw on cell wall composition: hydrophobicity and cellulase adsorption. Bioresour. Technol. 102, 5938-5946.

Heitner, C., Manley, R.S., Ahvazi, B., Wang, J., 2001. The effect of acetylation on the photodegradation of milled wood lignin. J. Pulp Paper Sci. 27, 325-329.

Holtman, K.M., Chang, H.M., Jameel, H., Kadla, J.F., 2006. Quantitative ${ }^{13}$ C NMR characterization of milled wood lignins isolated by different milling techniques. J. Wood Chem. Technol. 26, 21-34.

Huijgen, W.J.J., Smit, A.T., Reith, J.H., den Uil, H., 2011. Catalytic organosolv fractionation of willow wood and wheat straw as pretreatment for enzymatic cellulose hydrolysis. J. Chem. Technol. Biotechnol. 86, 1428-1438.

Huijgen, W.J.J., Telysheva, G., Arshanitsa, A., Gosselink, R.J.A., de Wild, P.J., 2014. Characteristics of wheat straw lignins from ethanol-based organosolv treatment. Ind. Crop. Prod. 59, 85-95.

Kanitskaya, L.V., Rokhin, A.V., Kushnarev, D.F., Kalabin, G.A., 1998. Chemical structure of wheat dioxane lignin studied by ${ }^{1} \mathrm{H}$ and ${ }^{13} \mathrm{C}$ NMR spectroscopy. Polym. Sci. Ser. A 40, 459-463.

Kim, Y., Yu, A., Han, M., Choi, G.W., Chung, B., 2010. Ethanosolv pretreatment of barley straw with iron(III) chloride for enzymatic saccharification. J. Chem. Technol. Biotechnol. 85, 1494-1498.

Lachenal, D., Mortha, G., Sevillano, R.M., Zaroubine, M., 2004. Isolation of residual lignin from softwood kraft pulp: advantages of the acetic acid acidolysis method. C. R. Biol. 327, 911-916.

Lapierre, C., Jouin, D., Monties, B., 1989. Lignin characterization of wheat straw samples as determined by chemical degradation procedures. In: Chesson, A Ørskov, E.R. (Eds.), Physico-Chemical Characterisation of Plant Residues for Industrial and Feed Use. Springer, Netherlands, pp. 118-130.

Lapierre, C., Monties, B., Rolando, C., 1986. Thioacidolysis of poplar lignins identification of monomeric syringyl products and characterization of guaiacyl-syringyl lignin fractions. Holzforschung 40, 113-118.

Lapierre, C., Monties, B., Rolando, C., 1988. Thioacidolyses of diazomethane-methylated pine compression wood and wheat straw in situ lignins. Holzforschung 42, 409-411.

Lequart, C., Kurek, B., Debeire, P., Monties, B., 1998. $\mathrm{MnO}_{2}$ and oxalate: an abiotic route for the oxidation of aromatic components in wheat straw. J. Agric. Food Chem. 46, 3868-3874.

McDonough, T.J., 1993. The chemistry of organosolv delignification. Tappi J. 76, 186-193.

Pan, X., Arato, C., Gilkes, N., Gregg, D., Mabee, W., Pye, K., Xiao, Z., Zhang, X Saddler, J., 2005. Biorefining of softwoods using ethanol organosolv pulping: preliminary evaluation of process streams for manufacture of fuel-grade ethanol and co-products. Biotechnol. Bioeng. 90, 473-481.

Pan, X.J., Gilkes, N., Kadla, J., Pye, K., Saka, S., Gregg, D., Ehara, K., Xie, D., Lam, D., Saddler, J., 2006. Bioconversion of hybrid poplar to ethanol and co-products using an organosolv fractionation process: optimization of process yields. Biotechnol. Bioeng. 94, 851-861.

Parr, R.G., Pearson, R.G., 1983. Absolute hardness - companion parameter to absolute electronegativity. J. Am. Chem. Soc. 105, 7512-7516.

Peng, J.P., Lu, F.C., Ralph, J., 1998. The DFRC method for lignin analysis. 4. Lignin dimers isolated from DFRC-degraded loblolly pine wood. J. Agric. Food Chem. 46, 553-560.

Prakash, G.K.S., Mathew, T., Olah, G.A., 2012. Gallium(III) triflate: an efficient and a sustainable lewis acid catalyst for organic synthetic transformations. Acc. Chem. Res. 45, 565-577.

Pye, E.K., Lora, J.H., 1991. The alcell process - a proven alternative to kraft pulping. Tappi J. 74, 113-118.

Ralph, J., Landucci 2010, L.L., 2014. Lignin and lignans. In: Heitner, C.. Dimmel, D.R. Schmidt, JA (Eds.), Advances in Chemistry. CRC Press, Boca Raton, USA, pp. $137-243$.

Ralph, S.A., Ralph, J., Landucci, L.L., 2004. NMR Database of Lignin and Cell Wall Model Compounds. Available at: URL http://ars.usda.gov/Services/docs.htm?docid=10491

Renard, C.M.G.C., Lahaye, M., Mutter, M., Voragen, F.C.J., Thibault, J.F., 1998 Isolation and structural characterisation of rhamnogalacturonan oligomers generated by controlled acid hydrolysis of sugar-beet pulp. Carbohydr. Res. $305,271-280$

Sluiter, A., Hames, B., Ruiz, R., Scarlata, C., 2008. Determination of Structural Carbohydrates and Lignin in Biomass. NREL/TP-510-42618. Available at: URL http://www.nrel.gov/docs/gen/fy13/42618.pdf

Socrates, G., 2001. Infrared and Raman Characteristic Group Frequencies, in: Wiley (Ed.), 3rd ed, Chichester, p. 104.

Stephen, J.D., Mabee, W.E., Saddler, J.N., 2012. Will second-generation ethanol be able to compete with first-generation ethanol? Opportunities for cost reduction. Biofuels Bioprod. Bioref. 6, 159-176.

Stewart, D., 2008. Lignin as a base material for materials applications: chemistry, application and economics. Ind. Crop. Prod. 27, 202-207. 
Sun, R.C., 2010. Lignin, cereal straw as a resource for sustainable biomaterials and biofuels. In: Chemistry, Extractives, Lignins, Hemicelluloses and Cellulose. Elsevier Science, Amsterdam, pp. p192.

Tamminen, T., 1999. Isolation and characterization of residual lignin. In: Argyropoulos, D.S. (Ed.), Advances in Lignocellulosics Characterization. Tappi Press, Atanta, pp. 1-42.

Tejado, A., Pena, C., Labidi, J., Echeverria, J.M., Mondragon, I., 2007.

Physico-chemical characterization of lignins from different sources for use in phenol-formaldehyde resin synthesis. Bioresour. Technol. 98, 1655-1663.

Thakur, V.K., Thakur, M.K., Raghavan, P., Kessler, M.R., 2014. Progress in green polymer composites from lignin for multifunctional applications: a review. ACS Sustain. Chem. Eng. 2, 1072-1092.

Wang, M.C., Leitch, M., Xu, C.B., 2009. Synthesis of phenol-formaldehyde resol resins using organosolv pine lignins. Eur. Polym. J. 45, 3380-3388.

Wildschut, J., Smit, A.T., Reith, J.H., Huijgen, W.J.J., 2013. Ethanol-based organosolv fractionation of wheat straw for the production of lignin and enzymatically digestible cellulose. Bioresour. Technol. 135, 58-66.

Xia, Z.C., Akim, L.G., Argyropoulos, D.S., 2001. Quantitative ${ }^{13} \mathrm{C}$ NMR analysis of lignins with internal standards. J. Agr. Food Chem. 49, 3573-3578.

Xu, F., Liu, C.F., Geng, Z.C., Sun, J.X., Sun, R.C., Hei, B.H., Lin, L., Wu, S.B., Je, J., 2006. Characterisation of degraded organosolv hemicelluloses from wheat straw. Polym. Degrad. Stab. 91, 1880-1886.
Yang, L., Li, Y., Savage, P.E., 2014. Hydrolytic cleavage of CO linkages in lignin model compounds catalyzed by water-tolerant Lewis acids. Ind. Eng. Chem. Res. 53, 2633-2639.

Yawalata, D., Paszner, L., 2004. Cationic effect in high concentration alcohol organosolv pulping: the next generation biorefinery. Holzforschung 58 7-13.

Yelle, D.J., Kaparaju, P., Hunt, C.G., Hirth, K., Kim, H., Ralph, J., Felby, C., 2013. Two-dimensional nmr evidence for cleavage of lignin and xylan substituents in wheat straw through hydrothermal pretreatment and enzymatic hydrolysis. Bioenerg. Res. 6, 211-221.

Zakzeski, J., Bruijnincx, P.C.A., Jongerius, A.L., Weckhuysen, B.M., 2010. The catalytic valorization of lignin for the production of renewable chemicals. Chem. Rev. 110, 3552-3599.

Zakzeski, J., Jongerius, A.L., Bruijnincx, P.C.A., Weckhuysen, B.M., 2012. Catalytic lignin valorization process for the production of aromatic chemicals and hydrogen. ChemSusChem 5, 1602-1609.

Zakzeski, J., Weckhuysen, B.M., 2011. Lignin solubilization and aqueous phase reforming for the production of aromatic chemicals and hydrogen. ChemSusChem 4, 369-378.

Zeng, J., Helms, G.L., Gao, X., Chen, S., 2013. Quantification of wheat straw lignin structure by comprehensive NMR analysis. J. Agric. Food Chem. 61 10848-10857. 